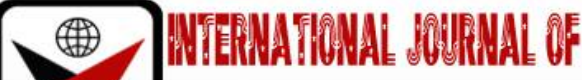

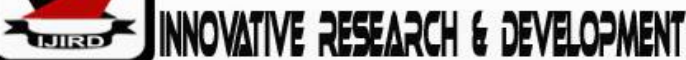

ISSN 2278 - 0211 (Online)

\section{Market Performance of Categorized Soybeans Marketers in Benue and Nasarawa State, Nigeria}

Abah Emmanuel Ogaje
Ph.D. Student, Department of Agricultural Economics,
Federal University of Agriculture, Makurdi, Benue State, Nigeria
Dr. Orefi Abu
Senior Lecturer, Department of Agricultural Economics,
Federal University of Agriculture, Makurdi, Benue State, Nigeria

\begin{abstract}
:
Analysis of market performance among soybean marketers in Benue and Nasarawa States was aimed at assessment of market performance in the study area. Purposive and multi-stage sampling was used. The two states were stratified into three agricultural zones each. Secondly, 30\% and 38\% of soybeans marketers were selected randomly selected from each zone of Benue and Nasarawa States respectively. 25\% of the categorized soybeans marketers (producermarketers, wholesalers, retailers and small-scale processors) were selected. This gave the total of 481 respondents. Data were collected through structured questionnaire and analyzed using descriptive statistics. The study revealed that most marketers were between the age of 41 and 60 years with average age of 39.99 year for small-scale processors, 44.06 years for wholesalers, 39.71 years for retailers and 42.77 years for producer-marketers. $75.7 \%$ of small-scale processors and $59.5 \%$ of retailers were female, while $69.8 \%$ of wholesalers and $70.7 \%$ of producer-marketers were male. Average years spent in school was 8.36 years; marketing experience was 9.96 years. Soybean producer-marketers

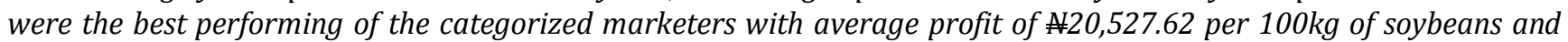
\#182,250.22 per annum on soybeans sold. Soybean wholesalers were the second in terms of performance with average profit of $\$ 4,756.23$ per $100 \mathrm{~kg}$ of soybean and $\$ 76,309.81$ per annum. However, soybean small-scale processors and retailers recorded low in terms of performance with average profit of $\$ 1,470.29$ per $100 \mathrm{~kg}$ or N7, 292.35 per annum for small scale processors and average profit of $\$ 1,351.89$ per $100 \mathrm{~kg}$ or $\$ 6,653.60$ per annum for soybean retailers. ANOVA and Post Hoc test revealed that there was significant difference in performance among the categorized soybeans marketers in terms of profit per bags, profit per annum, total cost expended and total sales value. This difference in performance was more pronounced between soybean producer-marketers and other categories of soybean marketers. The study recommends for more investment by farmer, producers and marketers in soybean business in other to enjoy the benefit of the practice. The government should make soybeans marketing and processing attractive by provision of regular supply of electricity, water and processing facilities. It also calls for the provision of subsidy such as fertilizers, improved seeds and agrochemicals by government and NGOs.
\end{abstract}

Keywords: Soybean producer marketers, small scale processors, wholesalers and retailers

\section{Introduction}

In other to tackle the challenges facing agricultural production and low yield, the production of highly nutritional varieties of crops and animals is advocated for world-wide. One of such crops is soybean ( $\underline{\text { Glycine }} \underline{\max }$ ). Soybean is generally considered as a highly versatile grain which has about 365 applications in the formulation of both human and animal foods and other industrial uses (Amusat \& Ademola, 2013). It provides a cheaper and high protein rich supplement to animal protein. It is an important crop in the world and has been the dominant oilseed since the 1960s (Shalma, 2014). It is a multipurpose crop and its importance ranges from its use in milk production, oil processing, livestock feeds, medicinal, industrial and human consumption and more recently, as a source of bio-energy (Shalma, 2014).

Soybean is produced mainly in the Guinea Savannah zone of Nigeria. However, it was reported that the crop is grown in rather small holder farms in most African countries including Nigeria (Shalma, 2014). Soybean is a productive and adaptable crop grown in most agro-climatic conditions. Its cultivation is not too demanding in terms of cultural practice compared to other crops such as yam. Soybeans can grow well in soil low in fertility because of the presence of root nodules as characteristics of leguminous crops. Soybean is a cheap source of quality protein that is superior to all other plant foods because it has good balance of the essential amino acids. Its seed has a close protein content and fairly close amino-acids compared to cow milk (Amusat \& Ademola, 2013).

Other than the high protein content, it also has good amount of calories and fat. The fat from the soybean is unsaturated type unlike saturated fats from animal origin and hence is good for heart disease patients (Amusat \& 
Ademola, 2013). It contains the eight essential amino acids and is a rich source of polyunsaturated fatty acids (including the good fat-omega 3) and is free of cholesterol. It is one of the best vegetarian food items as far as protein content is concerned, with an average production cycle of 90-110 days from planting to harvesting (Amusat \& Ademola, 2013).

Agricultural commodity marketing is a critical aspect of marketing that demand the attention of all market actors such as producers, middlemen, consumers and policy makers. The pivotal role marketing plays in reducing the problem of food security, poverty alleviation and tackling unemployment, has made the sector demanding attention of all market stockholders. It was observed that one important route to reduce poverty in rural areas is to enhance the market participation of rural farmers, as this can increase the net returns to agricultural production (World Bank, 2007). Many farmers in Sub-Saharan Africa however, remain subsistence farmers whose production activities are conducted mainly for home consumption (Verheye, 2000).

Nigerian agriculture has failed to supply sufficient food in quantity and quality to feed the constantly growing population (Abu, 2012). This failure could be attributed to the problem of agricultural marketing and food distribution. Agricultural marketing is be the main driving force for economic development, it drives and encourages production process by acting as a link between producers and consumers through delivery of feedback. However, Nigerian agricultural marketing is not performing optimally. Eze et al. (2010) observed inadequate processing equipment, poor marketing facilities, high cost of shops and inadequate packaging information as perceived constraints facing agricultural produce marketers in Enugu State, Nigeria. Tiri and Ojoko (2012) also observed high transaction costs and weak performance, resulting from high transportation cost, poor storage facilities and poor market infrastructure.

Furthermore, the lack of market for soybean output greatly hinder large scale production by farmers. Otitoju and Arene (2010) also observed that inadequate processing facilities ranked first among constraints faced by soybeans producers in Benue State, Nigeria. This has led to increase cost of marketing and reduction in level of return to marketer and reduction of quality and quantity to consumer.

This study is aimed at investigating the market performance of categorized soybean marketers in Benue and Nasarawa States, Nigeria and bridging such research gap in soybeans marketing in the study area. The specific objective is to describe socioeconomic characteristic of soybean marketers in the study area and to examine market performance of soybean marketers in the study area;

\section{Methodology}

This study was conducted in Benue and Nasarawa States, Nigeria. The two states are located in the middle belt region of Nigeria and share a common boundary. Benue State is located between latitudes 6.5응 $8.5^{\circ} \mathrm{N}$ of the Equator and longitudes 7.5 and 10 $\mathrm{E}$ of the Greenwich Meridian. Benue State has a total land area of about 30,955km ${ }^{2}$ and administratively it is divided into 23 Local government Areas (LGAs) and three Agricultural Zones (A, B and C). It has an estimated population of 5,741,815 inhabitants in 2016 (National Bureau of Statistics, 2017). Nasarawa lies between latitudes $7.45^{\circ}$ and $9.25^{\circ} \mathrm{N}$ of the equator and between longitudes $7^{\circ}$ and $9.37^{\circ} \mathrm{E}$ of the Greenwich Meridian. Nasarawa State has a land mass of 27,117 km² and population of 2,523,395 inhabitants in 2016 (National Bureau of Statistics, 2017). Nasarawa State capital is Lafia, it has 13 LGAs and is also divided into three Agricultural Zones.

Benue and Nasarawa States have similar soil type, vegetation and climatic condition. They have climate typical of the tropical zone because of their location. They are characterized by two distinct seasons dry and rainy seasons. The dry season spans from November to March, while the rainy season is from April to October. The two States have vast arable land for commercial farming, fishery development, wildlife and forestry conservation. Agriculture is the mainstay of the economy of the two States with over $70 \%$ of the population involved in subsistence and semi-subsistence agriculture. The states are major producer of food and cash crops like soybeans, cassava, yams, rice, maize and cowpea.

The sampling methods adopted include purposive, multi-stage and stratified sampling. In the first stage, the two states were stratified into three agricultural zones each. In the second stage, purposive selection of two LGAs from zone A and zone B and three LGAs were selected from zone C in Benue. Furthermore, purposive selection of two LGAs from northern and western zones and one LGA from southern zone of Nasarawa state was also done. In the third stage, the marketers were divided into producer-marketers, wholesalers, retailers and small-scale processors and $25 \%$ of them (producer-marketers, wholesalers, retailers and small-scale processors) were proportionately selected according to the population of soybean marketers in the LGAs.

Data for the study was collected by the use of structured questionnaire and analyzed using descriptive and inferential statistic such as mean, median, mode, ANOVA and Post Hoc test. Statistically,

means $\mu=\left(\sum X_{i}\right) / n$, also expressed as $\mu=\mathrm{x}_{1}+\mathrm{X}_{2}+\mathrm{X}_{3}+\ldots+\mathrm{X}_{\mathrm{n}} / \mathrm{n} \ldots \ldots$. (1)

Where: $\mu=$ sample mean

$\sum X_{i}=$ sum of all score in the sample e.g. $x_{1}, X_{2}, X_{3} \ldots X_{n}$

$\mathrm{n}=$ total number of individual or observation in the sample.

ANOVA can be represented by $Y i j=\mu+\bar{l}_{i}+\epsilon_{i j}$

Where: $\mu=$ mean

$\overline{\mathrm{l}}_{\mathrm{i}}=$ deviation from grand mean

$\epsilon_{\mathrm{ij}}=$ error terms

\section{Result and Discussion}

The study revealed that most soybean small-scale processors $(60.3 \%)$ and retailers $(65.80 \%)$ were between the age of 21 and 40 years, while $66.0 \%$ of soybean wholesalers and $59.7 \%$ of producer-marketers were between 41 and 60 years. This implied that most respondents are within the active working and productive age which is good for soybean 
marketing due to the labour-intensive task involved such as assemblage of output, lifting and weighing of several bags for long duration of time.

It was also found that soybean wholesalers comparably are older with mean age of 44.06 years, followed by producer-marketers (42.77 years), small-scale processors (39.99 years) and retailers (39.7 years). This is expected since wholesale business requires risk which can be well managed by mature mind. This result agreed with Ezihe et al. (2014) who found that majority (97.3\%) of soybean processors are within the active age of between 21 and 60 years with average age of 37 years and Uwaoma (2015) who found the average age of soybean processor in Anambra State, Nigeria to be 43 years. $75.7 \%$ of soybean small-scale processors and $59.5 \%$ of retailers were female. This could be as a result of women dominance in processing and marketing sectors of agricultural value-chain. This finding tallied with Uwaoma (2015) who found that $69 \%$ of soybean processing was done by female. However, $69.8 \%$ of wholesalers and $70.7 \%$ of producermarketers were male. This could be attributed to the large capital and labour required in soybean wholesale and direct production of soybeans. This corroborate Udeh et al.(2018b) where $77.3 \%$ of soybeans marketers in Benue State, Nigeria were male.

The predominant years spent in school was between 7 and 12 years, which implied that the marketers can read, write and record sales. Soybeans marketing actually requires lot of skills, calculation, record keeping and communication of feedback from marketers to producers, this make education a key requirement for a good marketer. Specifically, the secondary school-leavers were $39.7 \%$ of soybean small-scale processors, $60.4 \%$ of wholesalers, $42 \%$ of retailers and $42 \%$ of soybean producer-marketers. The next categories have spent 1-6 years in school (primary school leavers) as indicated by $38.2 \%$ of small-scale processors, $22.6 \%$ of wholesalers, $32.4 \%$ of retailers and $27.1 \%$ of producer-marketers.

The average years spent in school among soybean small-scale processors was 7.87 years, 9.89 years for wholesalers, 8.16 years for retailers and 7.50 years for producer-marketers. This implied that most soybeans marketers in the study area were quite literate and numerate. This result agreed with Asogwa and Okwoche (2012) where majority $(54 \%)$ of sorghum marketers in Benue State had secondary education.

\begin{tabular}{|c|c|c|c|c|c|c|c|c|}
\hline \multirow[t]{2}{*}{ Variable } & \multicolumn{2}{|c|}{$\begin{array}{l}\text { Small scale } \\
\text { Processors }\end{array}$} & \multicolumn{2}{|c|}{ Wholesalers } & \multicolumn{2}{|c|}{ Retailers } & \multicolumn{2}{|c|}{ Producers } \\
\hline & Frq. & $\%$ & Frq. & $\%$ & Frq. & $\%$ & Frq. & $\%$ \\
\hline \multicolumn{9}{|l|}{ Age } \\
\hline $21-40$ & 82 & 60.3 & 18 & 34.0 & 73 & 65.8 & 73 & 40.3 \\
\hline $41-60$ & 54 & 39.7 & 35 & 66.0 & 38 & 34.2 & 108 & 59.7 \\
\hline Total & 136 & 100 & 53 & 100 & 111 & 100 & 181 & 100 \\
\hline Mean & 39.99 & & 44.06 & & 39.71 & & 42.77 & \\
\hline \multicolumn{9}{|l|}{ Sex } \\
\hline Male & 33 & 24.30 & 37 & 69.80 & 45 & 40.5 & 128 & 70.70 \\
\hline Female & 103 & 75.70 & 16 & 30.20 & 66 & 59.5 & 53 & 29.30 \\
\hline Total & 136 & 100 & 53 & 100 & 111 & 100 & 181 & 100 \\
\hline \multicolumn{9}{|c|}{ Years in school } \\
\hline 0 & 22 & 16.2 & 4 & 7.5 & 19 & 17.1 & 45 & 24.9 \\
\hline $1-6$ & 52 & 38.2 & 12 & 22.6 & 36 & 32.4 & 49 & 27.1 \\
\hline $7-12$ & 54 & 39.7 & 32 & 60.4 & 47 & 42.0 & 76 & 42.0 \\
\hline$\geq 13$ & 8 & 5.9 & 5 & 9.4 & 9 & 8.1 & 11 & 6.1 \\
\hline Total & 136 & 100 & 53 & 100 & 111 & 100 & 181 & 100 \\
\hline Mean & 7.87 & & 9.89 & & 8.16 & & 7.50 & \\
\hline \multicolumn{9}{|l|}{ Market exp. } \\
\hline $1-5$ & 23 & 16.9 & 3 & 5.7 & 15 & 13.5 & 18 & 9.9 \\
\hline $6-10$ & 81 & 59.5 & 36 & 67.9 & 63 & 56.8 & 97 & 53.6 \\
\hline $11-15$ & 16 & 11.8 & 10 & 18.9 & 19 & 17.1 & 41 & 22.7 \\
\hline$\geq 16$ & 16 & 11.8 & 4 & 7.5 & 14 & 12.6 & 25 & 13.8 \\
\hline Total & 136 & 100 & 53 & 100 & 111 & 100 & 181 & 100 \\
\hline Mean & 9.44 & & 9.96 & & 9.95 & & 10.50 & \\
\hline \multicolumn{9}{|l|}{ Marital status } \\
\hline Married & 105 & 77.2 & 39 & 73.6 & 94 & 84.7 & 142 & 78.5 \\
\hline Singled & 16 & 11.8 & 8 & 15.1 & 12 & 10.8 & 17 & 9.4 \\
\hline Divorced & 3 & 2.2 & 2 & 3.8 & 4 & 3.8 & 5 & 2.8 \\
\hline Widowed & 12 & 8.8 & 4 & 7.5 & 1 & 0.9 & 17 & 9.4 \\
\hline Total & 136 & 100 & 53 & 100 & 111 & 100 & 181 & 100 \\
\hline
\end{tabular}

Table 1: Distribution of Respondents according to their Socioeconomics Characteristics Source: Field Survey, 2019

The study revealed that the marketing experience of most participants was between 6 and 10 years in soybeans marketing as indicated by $59.5 \%$ of small-scale processors, $67.9 \%$ of wholesalers, $56.8 \%$ of retailers and $53.6 \%$ of producer-marketers. Marketing experience is an advantage in line with the old saying state that 'practice makes perfect'. This is because what the marketers have done from previous years will usually serves as guide for future practices. 
According to Abah (2011), experience enhances proficiency and increase productivity. The next categories of marketing experience were between 11 and 15 years as indicated by $22.7 \%$ of soybean producer-marketers, $17.6 \%$ of retailers and $18.9 \%$ of wholesalers. It also revealed that the mean years of soybean marketing were 9.44 years, 9.96 years, 9.95 years and 10.5 years for small-scale processors, wholesalers, retailers and producer-marketers, respectively. However, Bakoji et al. (2013) found that 68\% soybeans marketers in Bauchi State, Nigeria have marketing experience of between 10 and 19 years.

Most soybean marketers were married as indicated by $77.2 \%$ of small-scale processors, $73.6 \%$ of wholesalers, $84.7 \%$ of retailers and $78.5 \%$ producer-marketers. This result implied that the marketers can get frequent productive advice, assistance and support from their spouse. This finding also corroborates Ezihe et al. (2014) who found that most $(67.9 \%)$ of soybean marketers in Tarka LGA of Benue state, Nigeria were married and Uwaoma (2015) who also found that 91\% of soybean processors in Anambra State, Nigeria were married.

Soybean market performance was analyzed based on profit made per annum and profit made per $100 \mathrm{~kg}$ of soybean as presented in table 2 . The analysis revealed that soybean producer-marketers made the highest profit ( $\$ 182$, 250.22) per annum in the study area. This could be attributed to long chain of activities involved by the producermarketers from point of land acquisition, production through processing and marketing. It could also be attributed to the used of direct marketing strategies which help them to minimize the activities of middlemen and their share of the profit along the marketing chain. This result is in tandem with Udeh et al. (2018a) where the marketing margins for soybeans producer marketers was higher than that of retailers and wholesalers in Benue State, Nigeria.

The result also revealed that soybean wholesalers were next in rank in terms of performance with profit of $\$ 76$, 309.81 per annum. This could be due to their large capital base, which may also be proportional to the amount invested. However, soybean small-scale processors and retailers made less profit per annum, averaging at $\$ 7,292.35$ and $\$ 6,653.60$ respectively. This could be attributed to less capital base and small amount invested. These categories of marketers need to do more, such as sourcing of fund (borrowing), making appreciable investment and improving their marketing skill in the soybeans business. However, result from the pooled data indicated an average of $¥ 80,586.32$ was made by all categories of marketers. This level of profit may seem high, but considering that soybean marketing was their main occupation, it is insufficient to cater for the soybean marketer's family needs.

\begin{tabular}{|c|c|c|c|c|c|c|c|}
\hline $\begin{array}{c}\text { Marketers } \\
\text { (Profit/Annum) }\end{array}$ & No. & Mean & Std. Dev. & Median & Mode & Mini. & Maxi. \\
\hline $\begin{array}{l}\text { Small-scale } \\
\text { processors }\end{array}$ & 136 & 7292.35 & 6695.48 & 6300 & 9450 & -10200 & 28350 \\
\hline Wholesalers & 53 & 76309.81 & 316816 & 11400 & 7500 & -500 & 2310750 \\
\hline Retailers & 111 & 6653.60 & 10983.43 & 4400 & 3500 & -5130 & 106650 \\
\hline Producer-marketers & 181 & 182250.22 & 109974 & 166200 & 99000 & 0.00 & 596600 \\
\hline Pooled & 481 & 80586.32 & 148777 & 12000 & 9450 & -10200 & 2310750 \\
\hline (profit/bag) & & & & & & & \\
\hline $\begin{array}{l}\text { Small-scale } \\
\text { processors }\end{array}$ & 136 & 1470.29 & 1171.95 & 1265.00 & 1050 & -1700 & 4600 \\
\hline Wholesalers & 53 & 4756.23 & $20,969.03$ & 1100.00 & 750 & -50 & 154050 \\
\hline Retailers & 111 & 1351.89 & 1455.32 & 1100.00 & 950 & -750 & 11850 \\
\hline Producer-marketers & 181 & 20527.62 & 7388.08 & 22850.0 & 18150 & 950 & 30500 \\
\hline Pooled & 481 & 8976.30 & 12274.47 & 2300.00 & 1050 & -1700 & 154050 \\
\hline
\end{tabular}

Table 2: Distribution of Respondents Based on Marketing Margin

Source: Field Survey, 2019

Soybeans market performance was also analyzed in term of profit made per $100 \mathrm{~kg}$ of soybeans. The result showed that soybean producer-marketers still lead other categories of marketers in the study area with average profit per 100kg of $\#$ 20,527.62. This profit could be attributed to unpaid family labour and unaccounted expenses incurred from point of production through grading and marketing. This angle of analysis allows the producers to see reason of increasing their scale of production and marketing in other to make more profit. Soybean wholesalers made average profit of $\$ 4,756.23$ per $100 \mathrm{~kg}$ of soybeans in the study area. This could be attributed to advantage inherent in bulk purchase by wholesaler, technical knowledge of wholesaler and their traditional drive for increase profit. This result agreed with Ani et al. (2016) who found marketing margin of soybeans wholesalers in Benue and Enugu State to be significantly higher than that of retailers.

The small-scale processors of soybean had average profit per $100 \mathrm{~kg}$ of $\$ 1,470.29$. This is very small but they are better marketers compared to the soybean retailers who made profit of $1,351.89$ per $100 \mathrm{~kg}$ of soybean. The slightly high profit made by soybean small scale processor comparable to soybean retailers could be attributed to the extra work involved in processing numerous soybeans output by the processor when compared to the soybean's retailers. However, the pooled of marketers made average profit of $\$ 8,976.30$ per $100 \mathrm{~kg}$ of soybeans. This is the reflection of the average profit per $100 \mathrm{~kg}$ made by all categories of soybean marketers. However, the result of market performance is below Udeh et al. (2018b) who found that producer-marketers received an average profit of $\$ 11,661.15$, soybean retailers received $\$$ $12,714.18$ and wholesalers received profit of $\$ 13,566.32$ per $100 \mathrm{~kg}$ of soybeans in Benue. 
The result of market performance was further subjected to ANOVA test to investigate if there was significant difference between and within the specified categories of soybeans marketers in terms of profit per $100 \mathrm{~kg}$, total cost, total sales and profit per annum. Table 3 showed that there was significant different in profit per $100 \mathrm{~kg}(\mathrm{~F}=188.31, \mathrm{p}<0.05)$ and profit per annum ( $\mathrm{F}=68.81, \mathrm{p}<0.05)$ between and within group of all the specified soybeans marketers. This implied that the profit per $100 \mathrm{~kg}$ or per annum made by one category of marketers was different from profit made by other categories. This could be attributed to the competitive advantage or expertise display by particular category of marketer. This result agreed with Achike and Anzaku (2010) who found significant difference in marketing margins among benniseed trader in Nasarawa State, Nigeria. The result also confirmed Biam and Tsue (2013) where they noted a significant difference among soybeans farmers in Benue State, Nigeria.

\begin{tabular}{|c|c|c|c|c|c|}
\hline Performance & $\begin{array}{c}\text { Sum of } \\
\text { square }\end{array}$ & Df & $\begin{array}{c}\text { Mean } \\
\text { square }\end{array}$ & F & Sig. \\
\hline Profit/bag Between Groups & $3.921 \mathrm{e} 10$ & 3 & $1.307 \mathrm{e} 10$ & 188.306 & 0.000 \\
Within Groups & $3.311 \mathrm{e} 10$ & 477 & $6.941 \mathrm{e} 7$ & & \\
Total & $7.232 \mathrm{e} 10$ & 480 & & & \\
\hline Total cost Between Groups & $3.369 \mathrm{e} 12$ & 3 & $1.123 \mathrm{e} 12$ & 206.353 & 0.000 \\
Within Groups & $2.596 \mathrm{e} 12$ & 477 & $5.443 \mathrm{e} 9$ & & \\
Total & $5.966 \mathrm{e} 12$ & 480 & & & \\
\hline Total sales Between Groups & $2.161 \mathrm{e} 12$ & 3 & $7.204 \mathrm{e} 11$ & 35.535 & 0.000 \\
Within Groups & $9.670 \mathrm{e} 12$ & 477 & $2.027 \mathrm{e} 10$ & & \\
Total & $1.183 \mathrm{e} 13$ & 480 & & & \\
\hline Profit/annum Between Groups & $3.209 \mathrm{e} 12$ & 3 & $1.070 \mathrm{e} 12$ & 68.805 & 0.000 \\
Within Groups & $7.416 \mathrm{e} 12$ & 477 & $1.555 \mathrm{e} 10$ & & \\
Total & $1.062 \mathrm{e} 13$ & 480 & & & \\
\hline
\end{tabular}

Table 3: ANOVA/Test of Significance of Soybeans Marketing Margins Source: Field Survey, 2019

There was also significant difference between and within group in terms of total $\operatorname{cost}(\mathrm{F}=206.35, \mathrm{p}<0.05)$ or total sales $(\mathrm{F}=35.54, \mathrm{p}<0.05)$ among the categorized soybeans marketers. This implied that total cost or sales among the categorized soybeans marketers was different. These differences could be traced to the level of commitment and the differences in experience among market participants. These corroborate Ani et al. (2016) who noted that costs and net margins were significantly different among marketers in Benue and Enugu States, Nigeria. The differences in profit per $100 \mathrm{~kg}$ and profit per annum were further subjected to a Post Hoc test to determine relationship among the market participants. Table 4 showed that there was significant difference in profit per $100 \mathrm{~kg}$ between small-scale processor and producer-marketer $(\mathrm{p}<0.05)$ confirm that producer-marketers are making more profit than other categories. However, there is no difference in profit between small-scale processor and wholesaler or retailer. Post Hoc was used by Ogunleye and Oladeji (2015) the result showed a significant difference in marketing activities between central agricultural zone and southeast zone of Nigeria.

Furthermore, the profit per $100 \mathrm{~kg}$ made by wholesaler was also significantly different from that of producermarketers $(\mathrm{p}<0.05)$. Whereas, no difference in profit per $100 \mathrm{~kg}$ between wholesalers and small-scale processors or retailers. There was significant different between retailer and producer $(p<0.05)$, while there was no different between retailer and processor or wholesaler.

Finally, there was significant difference in profit between producer-marketer and all other categories of marketers $(\mathrm{p}<0.05)$. This remarkable difference between producer and other categories could be attributed to involvement of producer in long chain from production through marketing. There was significant difference in profit per annum between processor and producer $(\mathrm{p}<0.05)$. There was significant difference between retailer and producer $(\mathrm{p}<$ 0.05). Furthermore, there was significant difference between producer-marketer and processor and between producer and retailers $(p<0.05)$. These differences could be attributed to peculiarity and difference in nature of practice exhibited by the categorized market participants.

\begin{tabular}{|l|l|l|l|l|l|}
\hline Variables & Marketer (I) & Marketer (J) & Mean Diff. (I-J) & \multicolumn{1}{|c|}{ Std Error } & \multicolumn{1}{c|}{ Sig. } \\
\hline Profit/bag & Small-scale & Wholesaler & -3285.93 & 2882.07 & 0.825 \\
& Processor & Retailer & 118.40 & 170.82 & 0.982 \\
& & Producer & -19057.30 & 558.27 & 0.000 \\
\hline & Wholesalers & Processor & 3285.93 & 2882.07 & 0.825 \\
& & Retailer & 3404.33 & 2883.63 & 0.802 \\
& & Producer & -15771.40 & 2932.20 & 0.000 \\
\hline & Retailers & Processor & -118.40 & 170.82 & 0.982 \\
& & Wholesaler & -3404.33 & 2883.63 & 0.802 \\
& & Producer & -19175.70 & 566.26 & 0.000 \\
\hline & Producer- & Processor & 19057.33 & 558.27 & 0.000 \\
& marketers & Wholesaler & 15771.40 & 2932.20 & 0.000 \\
& & Retailer & 19175.73 & 566.26 & 0.000 \\
\hline
\end{tabular}




\begin{tabular}{|c|l|l|l|l|l|}
\hline Variables & Marketer (I) & Marketer (J) & Mean Diff. (I-J) & \multicolumn{1}{|c|}{ Std Error } & Sig. \\
\hline Profit/annum & Small-scale & Wholesaler & -69017.46 & 43521.80 & 0.520 \\
& Processor & Retailer & 638.75 & 1190.14 & 0.995 \\
& & Producer & -174958 & 8194.42 & 0.000 \\
\hline & Wholesaler & Processor & 69017.46 & 43521.80 & 0.520 \\
& & Retailer & 69656.21 & 43530.50 & 0.510 \\
& & Producer & -105940 & 44279.08 & 0.113 \\
\hline & Retailer & Processor & -638.75 & 1190.14 & 0.995 \\
& & Wholesaler & -69656.21 & 43530.50 & 0.510 \\
& & Producer & -175597 & 8240.50 & 0.000 \\
\hline & Producer- & Processor & 174958 & 8194.43 & 0.000 \\
& marketer & Wholesaler & 105940 & 44279.08 & 0.113 \\
& & Retailer & 175597 & 8240.50 & 0.000 \\
\hline
\end{tabular}

Table 4: Post Hoc/Multiple Comparisons of Respondent's Profit

Source: Field Survey, 2019

\section{Conclusion and Policy Recommendations}

It was found that most soybean marketers were operating at their active and productive age. Soybean producer marketer and wholesalers were dominated by male gender while soybean processing and retailing was done mainly by female in the study area. Most soybean marketers are literate and numerate and have marketing experience of between 6 to 10 years. These attributes have contributed in enhancing their market performance.

Soybean producer-marketers made average profit of $\$ 20,527.62$ per $100 \mathrm{~kg}$ or $\$ 182,250.22$ per annum on soybeans sales. Wholesalers had average profit of $\$ 4,756.23$ per $100 \mathrm{~kg}$ or $\$ 76,309.81$ per annum of sales. Small-scale processors had average profit of $\$ 1,470.29$ per $100 \mathrm{~kg}$ or $\$ 7,292.35$ per annum and retailers' average profit of $\$ 1,351.89$ per $100 \mathrm{~kg}$ or $\$ 6,653.60$ per annum. There was significant difference in performance between the marketers in terms of profit per bags, profit per annum, total cost expended and total sales value among the categorized soybeans marketers. The difference in profit is more pronounce between producer-marketers and other categories of marketers. Hence the following recommendations were made:

- The profit made based on analysis market performance is encouraging, hence the soybeans value chain is recommended for producers and marketers as it will serve as means of employment and wealth creation.

- Soybeans production and marketing as found among producer-marketers should be encouraged by provision of subsidy such as fertilizers, improved seeds and agrochemicals by government and NGOs.

- The problem of lack of market can be addressed by government establishing soybean marketing board so as to regulate distribution and mop-up excess produce during peak harvest period and resale during period of relative scarcity.

\section{References}

i. Abah, E.O. (2011). Economics of Organic Solid Waste Utilization by Urban Small-scale Tomatoes Farmers in FCT Abuja, Nigeria. M.Sc. thesis. Department of Agricultural Economics, University of Nigeria, Nsukka, Nigeria. 70pp.

ii. Abu, 0. (2012). Food Security in Nigeria and South Africa: Policies and Challenges. Journal of Humanity and Ecology. 38(1): 31-35.

iii. Achike, I.A. and Anzaku, T.A. K (2010). Economic Analysis of the Marketing Margin of Benniseed in Nasarawa State, Nigeria. Agro-Science Journal of Tropical Agriculture, Food, Environment and Extension, 9(1):47-55.

iv. Amusat, A.S. and Ademola, A.O. (2013). Utilisation of Soybean in Oniyo Community of Oyo State, Nigeria.Global Journal of Science Frontier Research Agriculture and Veterinary.13(7):1-9.

v. Ani, D.P., Chidebelu, S.A.N. and Enete, A.A. (2016). Pricing Efficiency in Soybean Marketing: An Evaluation of Costs and Margins in Benue and Enugu States of Nigeria. American Journal of Agricultural Science. 3(4): 59-71.

vi. Asogwa, B.C. and Okwoche, V.A. (2012). Marketing of Agricultural Produce among Rural Farm Households in Nigeria: The case of Sorghum Marketing in Benue State. International Journal of Business and Social Sciences. 3(13): 269-227.

vii. Astewel, T. (2010). Analysis of Rice Profitability and Marketing Chain: The case of Fogera Woreda, South Gondar zone, Amhara National Regional State, Ethiopia's Thesis. School of Graduate Studies of Haramaya University, Ethiopia. 133pp.

viii. Bakoji I., Haruna U, Danwanka, H.A.and Jibril, S.A. (2013). Marketing Analysis of Soybeans (Glycirine max) in Toro LGA, Bauchi State, Nigeria. Research Journal of Agriculture and Environmental Management.2(11):358-364.

ix. Belewu M.A. and Belewu, K.Y. (2007). Comparative Physico-chemical Evaluation of Tiger- nut, Soybean and Coconut Milk Sources. International Journal of Agriculture and Biology.9(5): 785-787.

x. Biam, C.K and Tsue, P.T. (2013). Profitability of Soyabean Production by Small Holder Farmers in Nigeria: A Guide for Sustainable Food Security. European Journal of Business and Management.5(30): 89-96.

xi. Dawit, A. (2005). The Status and Challenges of Agricultural Marketing in Ethiopia. Paper Presented at a Panel Discussion Organized by the Ethiopian Association of Agricultural Professionals (EAAP), April 22. Ethiopian Agricultural Research Organization (EARO). 
xii. Eze, S.O., Onwubuya, E.A, Ezeh, A.N. (2010). Women Marketers' Perceived Constraints on Selected Agricultural Produce Marketing in Enugu South Area: Challenges of Extension Training for Women Groups in Enugu State, Nigeria. Agro-Science Journal of Tropical Agriculture, Food, Environment and Extension, 9(3): 215- 222.

xiii. Ezihe, J.A.C., Agbugba, I.K., and Iornum W. (2014). Economic Assessment of Rural Women Participation in Processing and Marketing of Soybeans in Tarka LGA Benue State, Nigeria. Current Agricultural Research Journal 2(1): 43-50.

xiv. National Bureau of Statistics (2017). National Population Estimates. Demographic Statistics Bulletine. Retrieved from nigerianstat.gov.ng on 20/06/2019.

xv. Nwalem, M.P., Ukpe, U.H., Djomo, R.F. and Dzever, D. (2016). Factors Influencing Market Participation Among Sesame Producers in Benue State, Nigeria. International Journal of Research studies in Agricultural Sciences. 2(5): $1-5$.

xvi. Ogunleye, K.Y. and Oladeji, J.O. (2015). Production and Marketing Performance of Farmers Participating in Cassava Initiative Across Agricultural Zones in Nigeria. Journal of Economics and Sustainable Development. 6(6): 108-116.

xvii. Omotayo, A.M., Olowe, V.I.O., Fabusoro, E., Babajide, J.M., Ojo, D.K. and Adegbite, $\quad$ D.A. (2007). Commercial Demand for Soybean in Nigeria. Making Nigerian Agricultural Markets Work for the Poor. PropCom Monograph Series 29. Agricultural Media Resources and Extension Centre (AMREC), Abuja. 67pp.

xviii. Otitoju, M.A. and Arene C.J. (2010). Constraints and Determinants of Technical Efficiency in Medium-scale Soybean Production in Benue State, Nigeria. African Journal of Agriculture Research.5(17): 2276-2280.

xix. Shalma, H. J. (2014). Economic Analysis of Soya Bean Production under Sasakawa Global 2000 Project in Kaduna State, Nigeria. MSc. thesis. Department of Agricultural Economics, Ahmadu Bello University, Zaria, Nigeria.

xx. Tiri, G.D. and Ojoko. E.A. (2012). Analysis of the Structural Characteristics of Sweet Orange Market in Kano Metropolis. Proceedings of the 46 Annual Conference of the Agricultural Society of Nigeria $5^{\text {th }}-9^{\text {th }} \quad$ November, J.M. Jibrin, J.M et al. (Edited) Pp 134-138.

xxi. Udeh, M., Ogbanje, C.E. and Ayopo, 0.0. (2018a). Analysis of the Marketing Margin of Soybeans in Benue State, Nigeria. International Journal of Environment, Agriculture and Biotechnology (IJEAB). 3(6): 944-950.

xxii. Udeh, M., Ogbanje, C.E. and Ayopo, 0.0. (2018b). Economic Analysis of Soybeans Marketing in Benue State, Nigeria. Academy of Agriculture Journal 3(6): 469-479.

xxiii. Uwaoma, I.G. (2015). Economics of Small-scale Soybean Processing Firms in Anambra State, Nigeria. Ph.D. thesis. Department of Agricultural Economics, University of Nigeria, Nsukka, Nigeria. 110pp.

xxiv. Verheye, W. (2000). Food Production or Food Aid? An African Challenge. Journal of Finance and Development. 37(4): 152-187.

xxv. World Bank (2007). World Development Report 2007: Agriculture for Development, Washington D.C. Retrieved from https://openknowledge.worldbank.org/handle/10986/5989 